\title{
ANALISIS PERANCANGAN APLIKASI GAME MENGGUNAKAN CORONA SDK PADA SMARTPHONE BERBASIS ANDROID
}

\author{
Purwati Retnowati $^{* 1}$ \\ Usman Rizal $^{\# 2}$ \\ ${ }^{*}{ }^{1 \# 2}$ Program Studi Sistem Informasi \\ Fakultas Ilmu Komputer \\ Universitas Bandar Lampung \\ Jl. Zainal Abidin Pagar Alam No. 26 \\ Labuhan Ratu Bandar Lampung 35142
}

\begin{abstract}
Game merupakan salah satu produk teknologi informasi yang cukup digemari saat ini, game juga merupakan bentuk aplikasi yang edukatif, artinya bisa dijadikan sebagai media pembelajaran dimana prosesnya bisa dilakukan dengan konsep belajar sambil bermain. Seperti layaknya sebuah perangkat lunak, game juga dibuat oleh sebuah perangkat lunak pembuat aplikasi game, dari beberapa aplikasi yang dapat membuat aplikasi game, disini penulis memberitahukan salah satu aplikasi membuat Game yang penulis bahas yaitu simulator corona SDK (Software Development Kit). Corona SDK merupakan simulator yang dipergunakan untuk membangun game 2 (Dua) dimensi khusus untuk pengembangan aplikasi game yang dapat berjalan pada smartphone berbasis Android, IOS, Kindle Fire dan NOOK. Namun tidak banyak pengguna yang mengenal simulator corona SDK, sehingga tidak banyak pengguna yang mengetahui cara membuat game yang berjalan di smartphone berbasis Android. Oleh sebab itu, penulis meneliti cara pembuatan game menggunakan simulator Corona SDK yang dituangkan pada penelitian analisis perancangan aplikasi game menggunakan corona sdk pada smartphone berbasis android.
\end{abstract}

Keywords : Game, Android, Corona SDK

\section{PENDAHULUAN}

\subsection{Latar Belakang}

Perkembangan teknologi dari waktu ke waktu kini semakin pesat, baik dari sisi perangkat keras maupun perangkat lunak. Terdapat berbagai perangkat lunak yang bersifat desktop-based, webbased hingga aplikasi yang dapat berjalan di smartphone. Smartphone menjadi alat bantu pintar yang memiliki banyak kemampuan yaitu untuk berkomunikasi dua arah, kemampuan multimedia seperti : memutar ulang video maupun audio, menjelajah di dunia maya dan menjalankan aplikasi atau Game. Namun tidak banyak pengguna yang mengenal simulator corona SDK, sehingga tidak banyak pengguna yang mengetahui cara membuat game yang berjalan di smartphone berbasis Android. Oleh sebab itu, penulis meneliti cara pembuatan game menggunakan simulator Corona SDK yang dituangkan pada penelitian analisis perancangan aplikasi game menggunakan corona sdk pada smartphone berbasis android

\section{Rumusan Masalah}

Berdasarkan pada permasalahan yang telah dijelaskan pada bagian latar belakang, maka rumusan masalah dapat disusun sebagai berikut :

a. Bagaimana cara membangun aplikasi game menggunakan simulator Corona SDK
(Software Development Kit) pada smartphone berbasis android?

b. Bagaimana cara mengimplementasikan aplikasi game pada smartphone berbasis android?

2.1 Batasan Masalah

Untuk membatasi cakupan dari pokok pembahasan dan permasalahan yang akan dipecahkan, maka dibuat batasan sebagai berikut :

a. Cara penggunaan simulator corona SDK (Software Development Kit) pada pembuatan aplikasi game yang akan berjalan di smartphone berbasis android.

b. Penelitian akan menghasilkan aplikasi game yang berjalan di Platform Android dari versi 2.2 dan diatasnya.

c. Dibatasi untuk responden pada Mahasiswa Fakultas Ilmu Komputer Universitas Bandar Lampung.

\section{TINJAUAN PUSTAKA DAN LANDASAN TEORI}

\section{Tinjauan Pustaka}

Untuk mendukung penelitian ini digunakan beberapa tinjauan pustaka yang relevan serta berkaitan dengan pokok bahasan yang diuji dalam aplikasi game pada smartphone berbasis android. Android merupakan sistem operasi yang banyak digunakan pada saat ini, baik pada telepon seluler maupun tablet, serta para pengguna sistem operasi android ini beragam dari kalangan pelajar sampai kalangan bisnis. Para pengguna bisa 
mengunduh aplikasi-aplikasi baik gratis, trial dan berbayar. Di Android Market memiliki banyak pilihan antara lain : Business, Education, Entertainment, Lifestyle, Music and Audio, Sport, Social, Tools, dll. Bahkan tersedia pilihan Medical untuk aplikasi yang disediakan, begitu banyak pilihan aplikasi yang bisa diunduh dan dimanfaatkan.

\section{Landasan Teori}

Software Engineering (Rekayasa

Perangkat Lunak) Menurut Janner Simarmata, Rekayasa perangkat lunak adalah sebuah profesi yang dilakukan oleh seorang perekayasa perangkat lunak yang berkaitan dengan pembuatan dan pemeliharaan aplikasi perangkat lunak dengan menerapkan teknologi dan praktik dari ilmu komputer,manajemen proyek, dan bidang-bidang lain nya. Perangkat lunak adalah instruksi langsung computer untuk melakukan pekerjaan dan dapat ditemukan di setiap aspek kehidupan modern dari aplikasi yang kritis untuk hidup (life-critical), seperti perangkat pemantauan medis dan pembangkit tenaga listrik sampai perangkat hiburan, seperti video game. Sejarah Singkat Sofware Engineering. Industri perangkat lunak telah berkembang melalui empat era, yaitu pada tahun 1950-an sampai tahun 1960an, tahun 1960-an sampai pertengahan tahun 1970an, pertengahan tahun 1970-an sampai tahun 1980an, dan pertengahan tahun 1980-an sampai sekarang. Setiap era memiliki karakteristik khusus dan setiap tahun nya perangkat lunak mengalami peningkatan,baik dalam ukuran maupun kompleksitasnya.

Tahapan Membuat Game

a. Menentukan Genre Game

Hal pertama yang harus dipikirkan sebelum membuat game adalah menentukan jenis game yang ingin kita buat, apakah berjenis, RPG(Role Playing Game) seperti harvest moon, FPS(First Person Shooter) seperti Counter Strike, SPS(Second PersonShooter) seperti 25 To Life, Arcade seperti Riden, Fighting seperti Street Fighter, Racing seperti Need For Speed, atau RTS(Real Time Strategy) seperti Age Of Empire atau Casual Game seperti Abduction! World. Dengan menentukan genre game akan lebih memudahkan untuk membuat game. Disarankan pilihlah jenis game yang sesuai dengan kemampuan yang dimiliki, mudah dan cepat dalam pembuatannya.

b. Menentukan Tool yang digunakan Ini merupakan bagian yang terpenting, yaitu menentukan tool yang akan digunakan untuk membuat game. Gunakanlah tool yang biasa digunakan untuk mempermudah dalam pembuatan game. c. Menentukan gameplay game, Gameplay adalah sistem jalannya game tersebut, mulai dari menu, area permainan, save, load, game over, story line, misiion sukses, mission failed, cara bermain dan sistem lainnya harus ditentukan, misal ketika dalam menu pemain hanya akan mendapat pilihan menu play game, load game, credit dan quit. Semua sistem yang digunakan dalam game disebut dengan gameplay.

d. Menentukan grafis yang ingin digunakan Setelah membuat gameplay selanjutnya menentukan grafis yang akan digunakan. Jenis grafis secara sederhana dapat dibagi menjadi tiga jenis yaitu jenis kartun, semi realis, atau realis. Pilih jenis grafis yang sesuai dengan kebutuhan, kemudian pilih software apa yang akan digunakan dalam membuat gambarnya.

e. Menentukan suara yang ingin digunakan Tanpa suara akan membuat game akan kehilangan nilainya, karena itulah pilih suara yang ingin digunakan dalam permainan. Pilihan suara bisa dibagi-bagi menjadi beberapa bagian seperti bagian main menu, save menu, load menu, shoot, dead, mission sukses, mission failed, loading dan bagianbagian lainnya, pemilihan suara yang digunakan harus seirama, kemudian pilih software yang akan digunakan untuk membuat atau mengedit suara yang akan digunakan dalam game.

f. Melakukan perencanaan waktu, Dengan perencanaan waktu sudah dijelaskan apa yang harus dilakukan sehingga akan memberikan kemudahan dalam membuat game. Selain itu akan sangat membantu dalam penyelesain sesuai dengan deadline. Perencanaan waktu pembuatan sangat baik untuk dilakukan.

g. Proses pembuatan, Yang terakhir lakukan pembuatan game karena semua komponen yang diperlukan sudah disiapkan dari awal, lakukan proses pembuatan berdasarkan waktu yang sudah ditentukan.

h. Melakukan publishing, Ketika sudah selesai membuat sebuah game, selanjutnya mempublish game. Untuk aplikasi android dapat di publish di Android Market. (A.Zuli : 2012)

\section{Corona SDK}

Corona SDK merupkan tool dari Ansca Mobile. Berbeda dengan ketiga tool diatas, Corona SDK bisa dikatakan sebagai tool yang memiliki kemampuan yang tinggi, dengan menggunakan Corona SDK, Anda dapat membuat aplikasi, game maupun e-book yang lebih kompleks. Corona ini adalah software untuk membuat aplikasi Android khususnya untuk game development. Walau sebenarnya lebih tepat untuk animasi. Tapi untuk game, corona termasuk yang populer dan top. 
Bahasa pemrograman yang digunakan adalah bahasa luar.

\section{JDK}

Dalam rangka untuk menulis program Java, Developer tentu saja memerlukan lingkungan pengembangannya. Waktu buku ini sedang ditulis, Sun's Java Development Kit memberikan semua yang dibutuhkan untuk mulai menulis program Java. JDK tersedia untuk Sun SPARC yang menjalankan Solaris 2.2 atau lebih tinggi dan untuk Windows NT dan Windows 95. Para pengembang bisa mendapatkan JDK dari beberapa tempat. Smartphone Menurut Ali Zaki Secara harfiah artinya telepon pintar, yakni telepon seluler yang memiliki kemampuan seperti PC wallaupun terbatas. Selain itu ,Smartphone juga mendukung email dan organizer. Fiitur lainnya adalah kemampuannya untuk ditambah aplikasi-aplikasi baru.

\section{Android}

MenurutZechner Mario Android adalah susunan dari beberapa perangkat lunak (software stack). Stack ini secara umum meliputi sistem operasi, middleware, dan aplikasi-aplikasi kunci. Android awalnya tidak dikembangkan oleh google, melainkan dikembangkan oleh sebuah perusahaan bernama Android Inc. Karena melihat banyak user yang online dengan perangkat mobile, maka google melihat peluang yang sangat besar bahwa perangkat mobile ini memiliki masa depan cerah, sehingga Android Inc diakusisi oleh Google pada tahun 2005.

\section{Arsitektur Android}

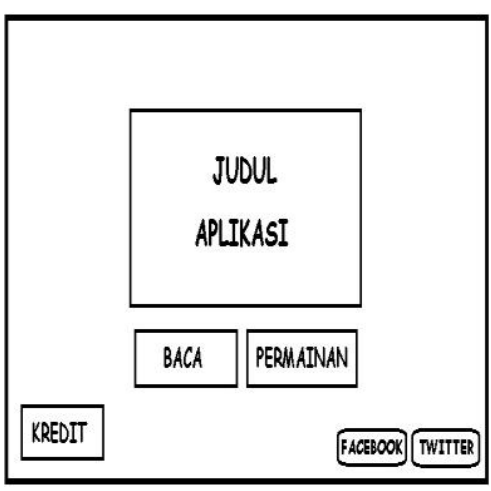

Gambar 1 Arsitektur Android

Dalam paket sistem operasi Android tediri dari beberapa unsur seperti tampak pada gambar 2.2. Secara sederhana arsitektur Android merupakan sebuah kernel Linux dan sekumpulan pustaka C / C++ dalam suatu framework yang menyediakan dan mengatur alur proses aplikasi. (mario : 2011)

\section{Metodologi Penelitian}

Aplikasi game Advanture ini dibuat dengan bahasa pemrograman Lua dan menggunakan perangkat lunak IntellijIDEA, yang dikombinasikan dengan Corona SDK dan Lua Compiler.

\section{Analisis Sistem dan Teknik Pengumpulan Data}

Salah satu faktor penting dalam pembangunan/pengembangan sistem informasi ialah memahami sistem yang ada dan permasalahannya. Selain harus mengetahui bagianbagian mana saja yang di pelajari, selain itu juga harus memilih teknik yang tepat untuk mengumpulkan data. Teknik yang digunakan pada penelitian ini adalah teknik Wawancara (interview), teknik pengamatan langsung (observasi), teknik daftar pertanyaan (Questioner), dan studi literatur. Adapun uraian secara kongkrit dari teknik pengumpulan data di atas akan di uraikan dibawah ini.

\section{Desain Perangkat Lunak}

Desain perangkat lunak yang digunakan untuk merancang Aplikasi Game "Neil Menjaga Hutan". Awal sebelum pembuatan game "Neil Menjaga Hutan" ini dengan menggunakan konsep dan tahapan dalam perancangan Aplikasi Game ini.

I. Pembuatan desain / storyboard (alur game) Game "Neil Menjaga Hutan" akan di rancang dengan 8 level dan dengan tingkat kesulitan makin tinggi. Game ini memiliki 2 bagian yaitu : Baca dan Permainan.. Langkah-langkah yang dilakukan yaitu :

1. Perancangan Antarmuka

$$
\begin{array}{ll}
\text { a. } & \text { Template Halaman Baca } \\
\text { b. } & \text { Menu Utama } \\
\text { c. } & \text { Credit } \\
\text { d. } & \text { Halaman 1 sampai } 7 \\
\text { e. } & \text { Menu permainan } \\
f . & \text { Game Level 1-3 dan Level 7-9 } \\
\text { g. } & \text { Petunjuk Permainan Ke-2 } \\
\text { h. } & \text { Game Level 4-6 dan Level 10-12 } \\
\text { i. } & \text { Menu pop up 1-2 }
\end{array}
$$

II. Desain level / flowchart

Tahap ini untuk desain tiap level game. Misal system permainannya: pemain harus dapat membersihkan sampah Gambar 2. Desain Level

sebanyak-banyaknya dan mengumpulkan minimal 10 point dalam waktu 10 detik. Adapun tahap perancangan game ini menggunakan Flow-chart. 
III. Desain character

Desain karakter yang akan digunakan pada game, misal Kuda Nil -> nama: neil, Burung Beo -> nama Beo

IV. Desain interface

Tahap ini menggambar bentuk wajah binatang yang jarang di lihat dan jarang dikenal orang, yaitu binatang "kudanil", tombol dan Icon

1. Asset-asset game yang dipersiapkan:

1) Asset Background - foreground

2) Asset Game (item game)

3) Asset Icon

4) Asset Tetap

5) Asset Text

6) Asset Tombol

7) Credit

8) Menu

9) Menu game

10) Scene 1-6

11) Finishing

Tahap perapian gambar, membagi layer yang akan di export, export gambar yang telah selesai pewarnaannya dari photoshop ke PNG. Setelah itu gambar ini dapat di implementasikan ke tahap selanjutnya.

\section{PEMBAHASAN}

Pembahasan ini tentang membangun Aplikasi Game "Neil Menjaga Hutan". Tahap yang akan dilakukan dalam pembahasan ini sebagai berikut :

\section{a. Menu Utama}

Gambar 4.2 merupakan rancangan untuk menu awal aplikasi. Pada menu utama terdapat tombol untuk kredit, baca, permainan dan share ke facebook dan twitter.

\section{b. Credit}

Perancangan antarmuka untuk halaman credit dapat dilihat pada gambar 4.3.

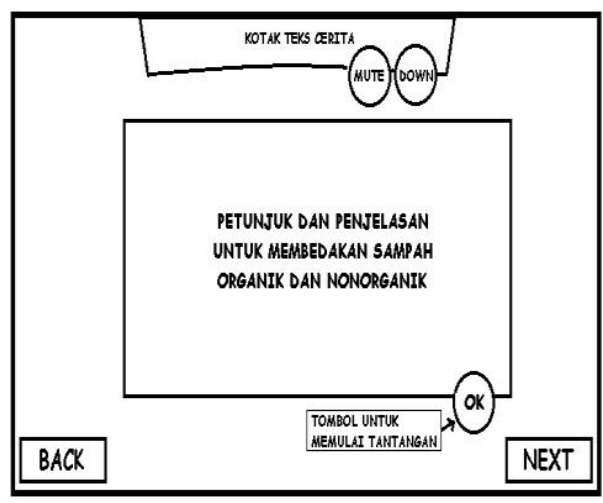

Gambar 3. Interface halaman credit

\section{c. Menu Permainan}

Berikut ini merupakan rancangan antarmuka untuk menu permainan. Pada perancangan ini level permainan disusun dalam bentuk tabel. Pada 1 halaman maksimal pilihan level yang dapat dilihat oleh user adalah sebanyak 6 level.

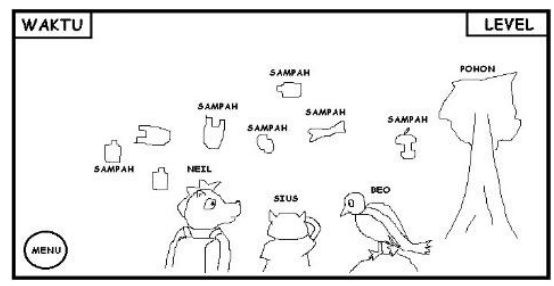

Gambar 4. Menu permainan

Untuk melihat level 7-12 user dapat menarik (drag) menu permainan supaya bergeser, maka level 7-12 akan muncul pada halaman menu permainan.Rancangan tersebut dapat dilihat pada gambar 4.11 .

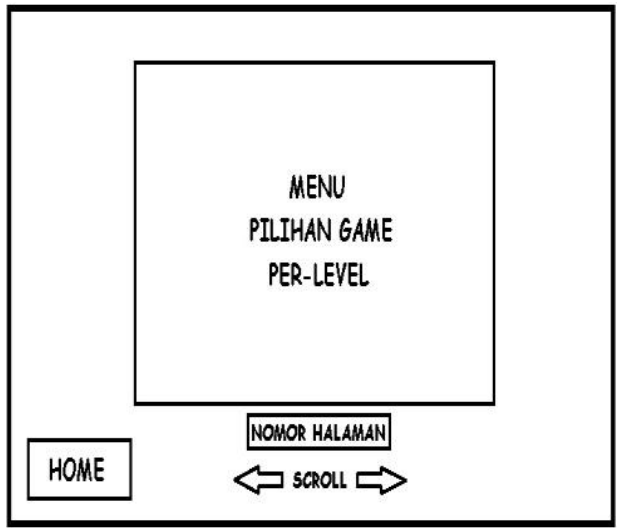

Gambar 5. Menu pilihan game

\section{d. Game Level 1-3 dan Level 7-9}

Berikut ini merupakan rancangan antarmuka untuk game pada level 1 sampai 3 dan level 7 sampai 9. Pada level ini user diminta membersihkan sampah dengan cara menyentuhnya sebanyak mungkin dan secepat mungkin dalam waktu yang telah ditentukan. Rancangan tersebut dapat dilihat Gambar 5. 


\section{e. Petunjuk Permainan Ke-2}

Pada gambar 3.12 merupakan rancangan untuk petujuk permainan level 4 sampai 6 dan level 10 sampai 12 , tetapi petunjuk ini hanya akan muncul 1 kali yaitu pada saat permainan sampai di level 4.

\section{f. Petunjuk Permainan Ke-2}

Pada gambar 3.12 merupakan rancangan untuk petujuk permainan level 4 sampai 6 dan level 10 sampai 12 , tetapi petunjuk ini hanya akan muncul 1 kali yaitu pada saat permainan sampai di level 4. Rancangan tersebut dapat dilihat pada Gambar 6.

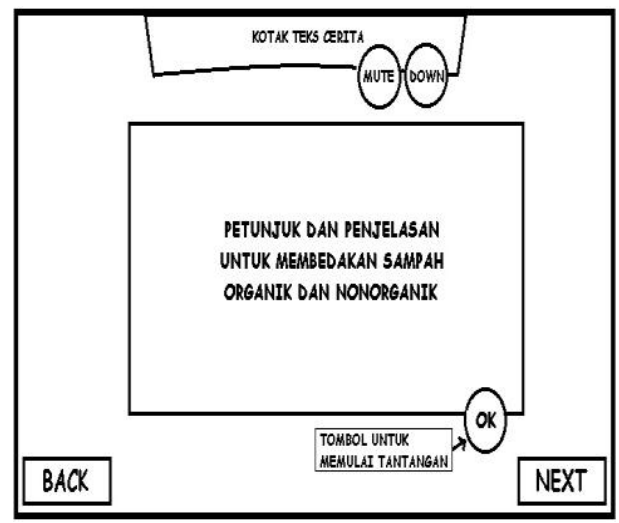

Gambar 6. Petunjuk Permainan Level 4-6

I. Desain level / flowchart

Tahap ini untuk desain tiap level game. Misal system permainannya: pemain harus dapat membersihkan sampah sebanyakbanyaknya dan mengumpulkan minimal 100 point dalam waktu 10 detik.

II. Desain interface

Desain interface ini dibuat untuk cerita dalam game yang menentukan Item

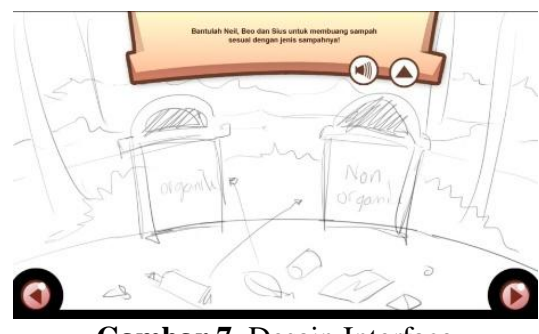

Gambar 7 Desain Interface

1. asset-asset game:

1) Asset Background - foreground

Pada Gambar 8 merupakan folder halaman untuk aplikasi game ini, sehingga dari awal sampai akhir aplikasi menggunakan template tersebut. Gambar dibawah merupakan rancangan untuk folder halaman Game.

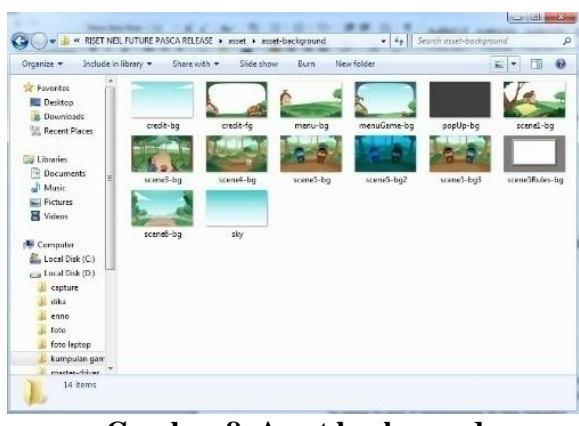

Gambar 8. Asset backgound

2) Asset Game (item game)

Pada Gambar 4.20 ini item yang di buat untuk inti dari permainan yang dirancang.

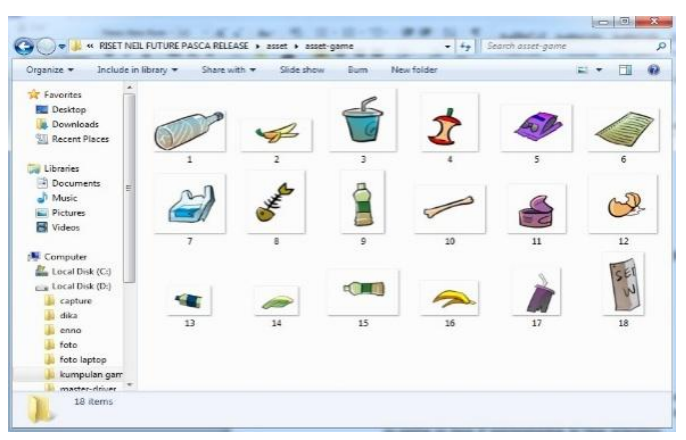

Gambar 9. Asset Game (Item Game)

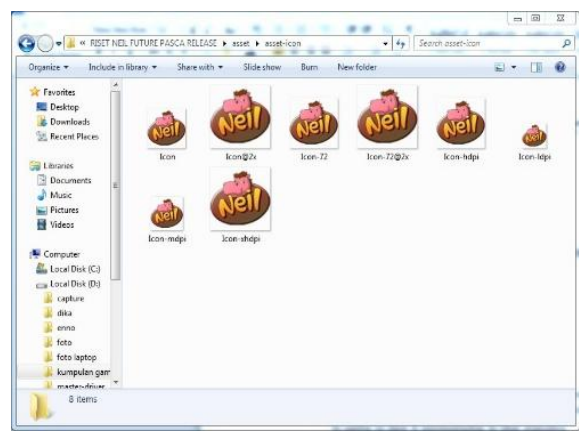

Gambar 10. Folder icon yang akan digunakan

3) Asset Tetap

Gambar 11 ini merupakan asset yang berfungsi sebagai memperlihatkan skor permainan

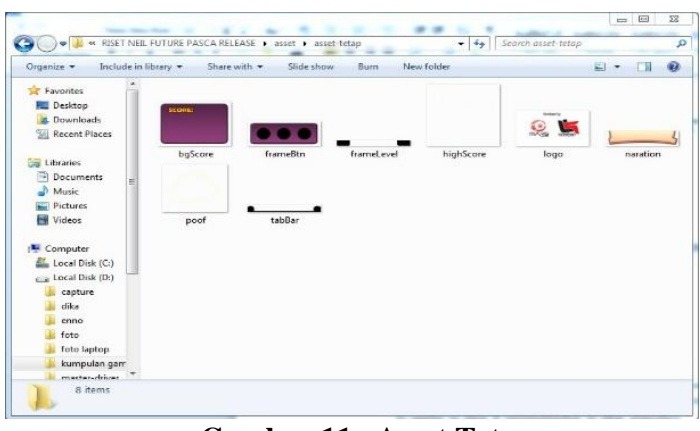

Gambar 11. Asset Tetap 
4) Asset Text

Gambar 12 ini text yang dibuat untuk menunjukan cerita dongeng didalam game.

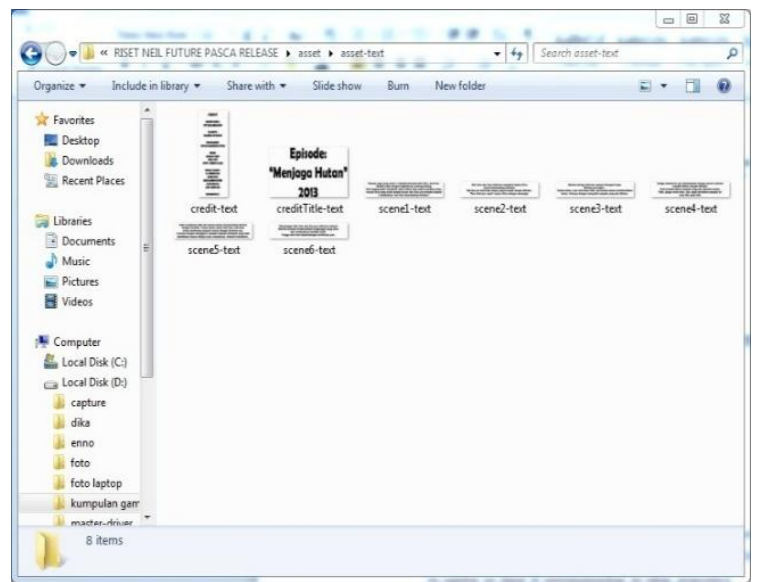

Gambar 12. Asset TexT

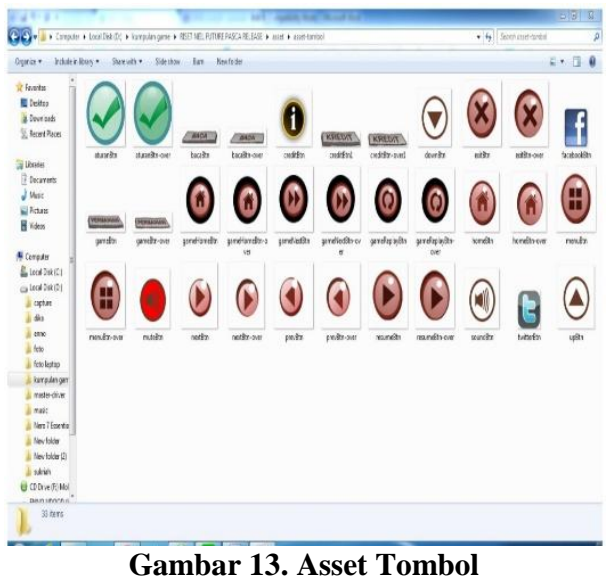

5) Asset Tombol

Asset tombol ini untuk menentukan arah yang bisa di sentuh oleh pemain.

6) Credit

Gambar credit ini untuk tampilan awal, menunjukan bahwa game ini telah $d$ support oleh lambing logo-logo yang di tampilkan sebagai credit.

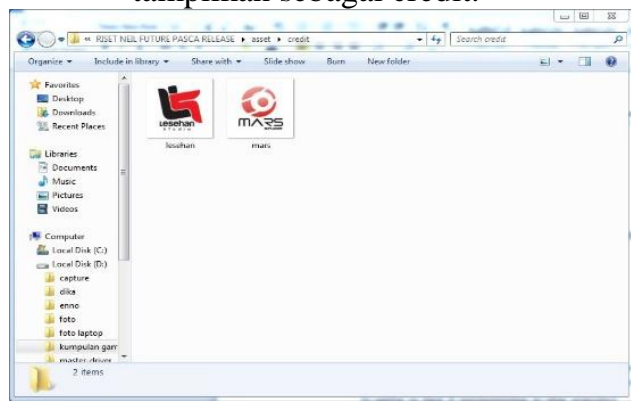

Gambar 14. Credit tampilan depan

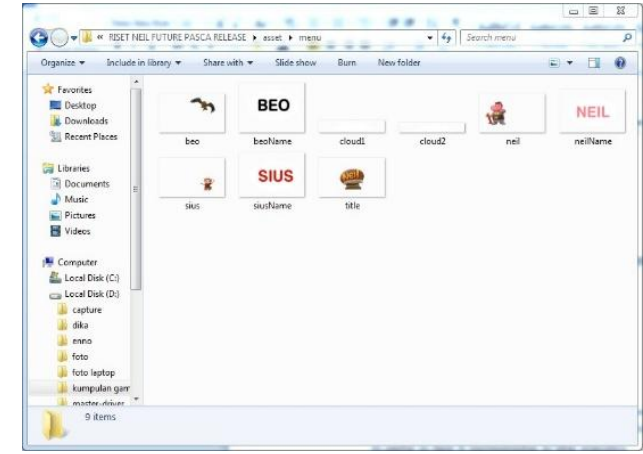

Gambar 15. Menu

7) Menu

Gambar ini dapat disentuh dan menimbulkan suara saat bermain,dan lambing nama itu untuk menunjukan namanama karakter.

8) Menu Game

Gambar ini untuk menentukan level dan score.

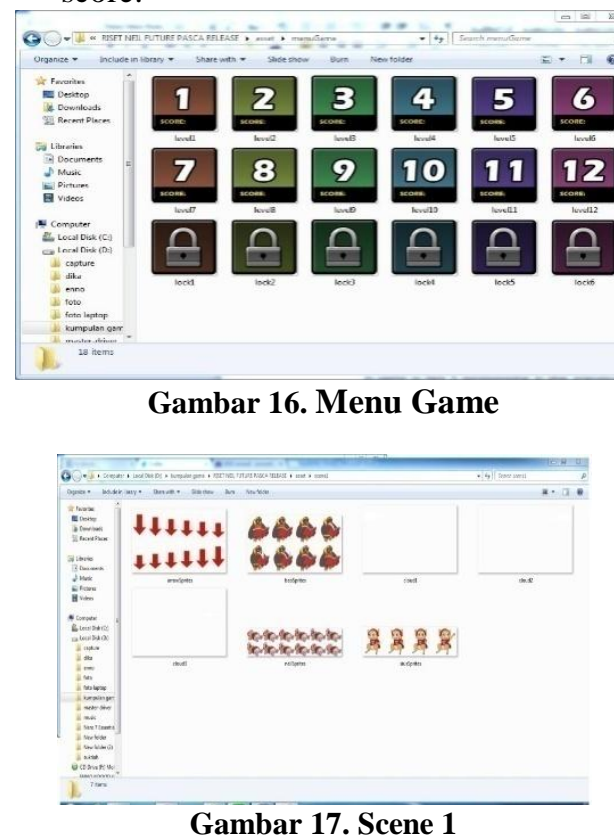

9) Scene

Gambar scene menggabungkan gambar dalam bentuk file PNG, jika digerakan akan terus menerus bergerak.

10) Finishing

Tahap perapian gambar, membagi layer yang akan di export, export gambar yang telah selesai pewarnaannya dari photoshop ke PNG. Setelah itu gambar ini dapat di implementasikan ke tahap selanjutnya.

\section{Implementasi Perangkat Lunak}

1. Aktivasi corona SDK

Gambar 18 Corona SDK yang harus di aktivasikan ke internet 
http://coronalabs.com/ sign up terlebih dahulu untuk memiliki account Corona SDK .aktivasi ini dapat mendownload Software Corona SDK dan dapat membuat program berjalan.

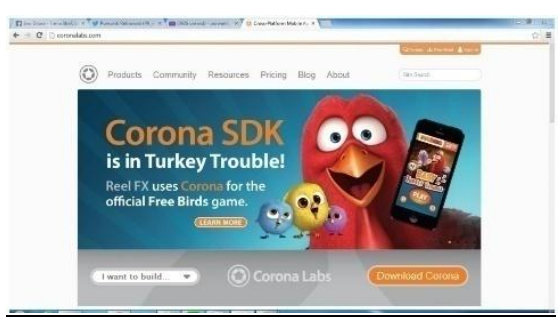

Gambar 18. Membuka web Corona SDK

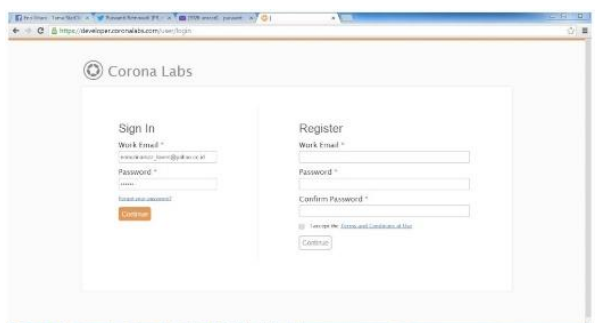

Gambar 19. login atau registrasi Corona

2. Corona SDK

Pada Gambar 24 Setelah mendownload dan menginstal Software Corona SDK,buka dan aktifasikan Corona SDK dengan email dan password yang digunakan saat aktivasi internet Corona SDK.

Gambar 20 tampilan Corona SDK setelah selesai login, samakan masukan email dan password ketika registrasi/ login di web.

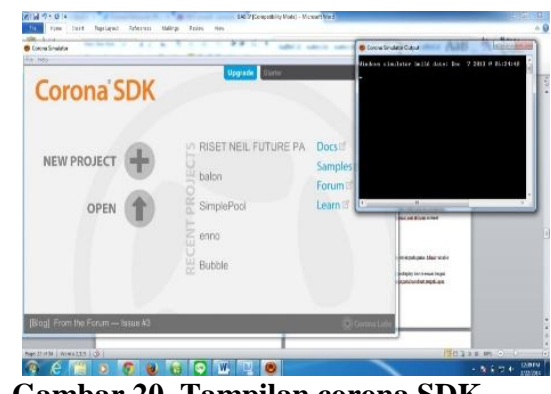

Gambar 20. Tampilan corona SDK

Seperti pada gambar di atas, tahap ini membuat projek baru Setelah itu file akan tersimpan di folder yang sudah ditentukan.

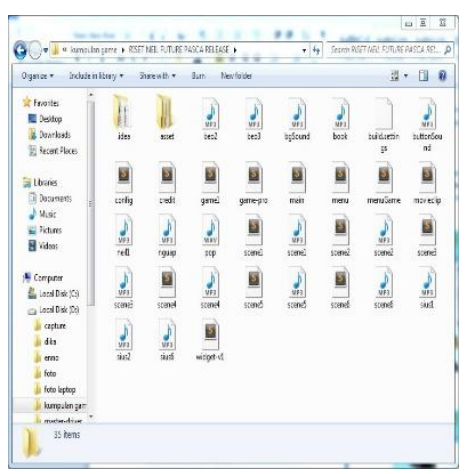

Gambar 21. Folder penyimpanan project

Tampilan Simulator Corona SDK dan siap menerima panggilan untuk menampilkan uji coba game yang telah disusun.

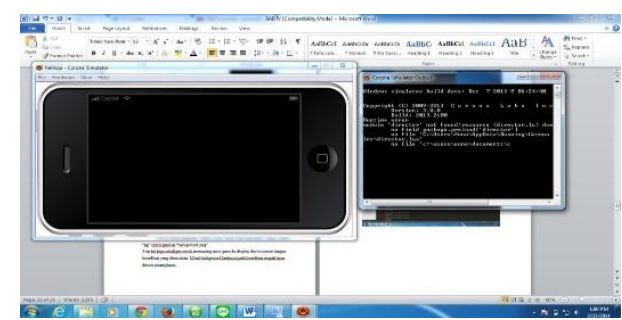

Gambar 22. Tampilan Corona yang siap menerima project dari Sublime Text

3. Pembuatan program

a. Pembuatan variable

Step ini untuk membuat variable untuk setiap objek pada game. Misal variable "bg" untuk gambar "background.png" Step ini juga sekaligus untuk memasang asset game ke display device sesuai dengan koordinat yang ditentukan. Misal background letaknya pada koordinat tengah layar device smartphone.

Pembuatan Event listener gunanya untuk mengetahui event yang terjadi. Misal jika user melakukan sentuhan pada layar maka akan diketahui koordinat sentuhannya, jumlah sentuhan, lama sentuhan, dll.

Jenis - jenis listener:

- Touch (sentuh)

- Tap

- EnterFrame (deteksi awal frame)

- Collision (deteksi tumbukan), dll

Gambar 23 ini tampilan pembuka Sublime text yang berfungsi sebagai menggerakan

gambar dan suara yang sebelumnya disimpan di Corona SDK. 


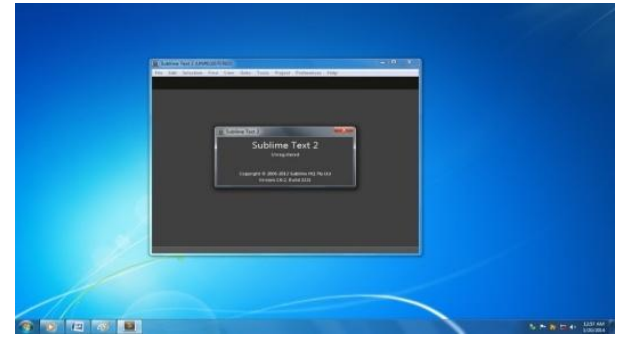

Gambar 23. Sublime sebagai text editor

Tampilan Text Editor Sublime saat melakukan penyusunan gambar dan memberikan efek berjalannya permainan.

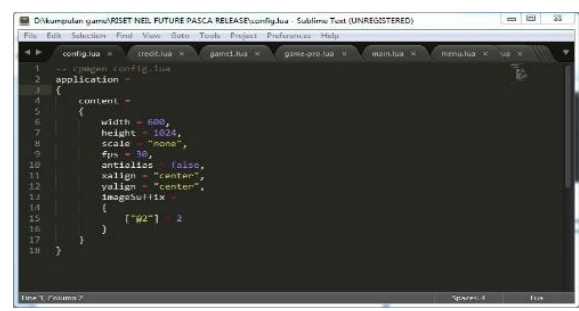

Gambar 24. pemrograman melalui sublime text

4. Implementasi Antarmuka

Berikut ini merupakan hasil implementasi antarmuka yang telah diterapkan pada `aplikasi game berbasis android.

a. Implementasi Menu Utama

Pada menu utama terdapat menu baca, permainan, i serta menu share ke facebook dan twitter. Ketika pengguna menekan menu baca maka akan menuju ke halaman scene. Menu permainan akan menuju ke halaman memilih level game. Jika pengguna menekan menu i maka akan menuju ke halaman credit. Pengguna dapat share aplikasi ini melalui sosial media facebook dan twitter. Implementasi menu utama dapat dilihat dibawah ini pada

\section{Gambar 25}

b. Implementasi Halaman Credit Halaman credit merupakan penjelasan mengenai tim yang ikut terlibat dalam

pembuatan apikasi storytelling. Implementasi halaman credit dapat dilihat pada gambar 4.39 dibawah ini.

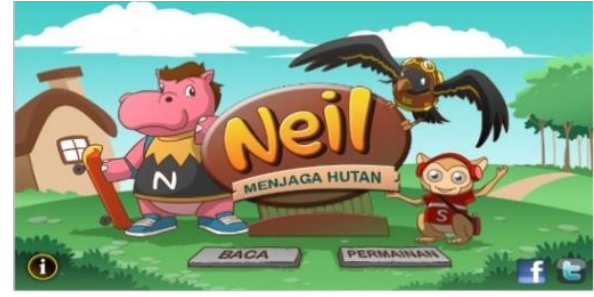

Gambar 25. Implementasi Halaman Credit

c. Implementasi Halaman Scene

Halaman scene merupakan halaman yang berisi tampilan konten cerita yang terdapat pada aplikasi. Cerita berisi narasi tentang pertualangan ketiga tokoh karakter yaitu beo, neo

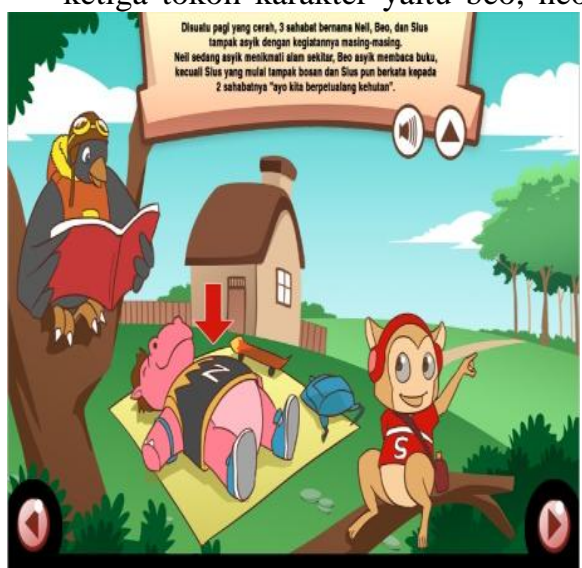

dan sius. Narasi berupa tulisan dan suara. Implementasi untuk halaman scene dapat dilihat pada Gambar 26

d. Implementasi Menu Permainan Terdapat 12 level permainan

\section{Gambar 26. Halaman scene}

yang dapat dipilih oleh pengguna pada menu permainan. Setiap level permainan memiliki waktu permainan yang berbeda-beda. Level 1 sampai 3 dan level 7 sampai 9 merupkan permainan untuk pengguna membantu 3 tokoh karakter mengumpulkan sampah yang terdapat didalam hutan. Pada level 4 sampai 6 dan level 10 sampai 12 merupakan permainan pengguna membantu 3 tokoh karakter mengumpulkan dan memisahkan sampah organik dan non -organik. Banyaknya sampah di hutan tergantung tingkat level 
permainan. Semangkin tinggi level permainan maka sampah yang terdapat di hutan semakin banyak. Pengguna dapat memainkan permainan ke level yang lebih tinggi jika terah melakukan permainan sebelumnya. Implementasi Menu permainan dapat dilihat pada Gambar 27

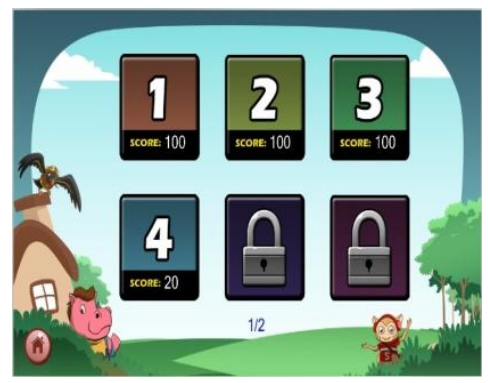

Gambar 27. Menu permainan

e. Implementasi Permainan 1

Implementasi permainan 1 merupkan salah satu contoh permainan pada level 1, 2, 3, 7, 8 dan 9. Yang membedakan setiap level permainan yaitu banyaknya sampah yang terdapat di hutan dan waktu permainan.

f. Implementasi Menu Popup 1

Menu popup 1 merupakan tampilan ketika pengguna memainkan game dan menekan menu home. Menu popup ini berisi menu resume, replay dan exit. Menu resume berfungsi untuk melanjutkan permainan. Menu replay berfungsi untuk mengulang permainan pada level yang sama serta menu exitberfungsi keluar dari permainan dan menuju ke menu permainan. Implementasi dari menu popup 1 dapat dilihat pada Gambar 28.

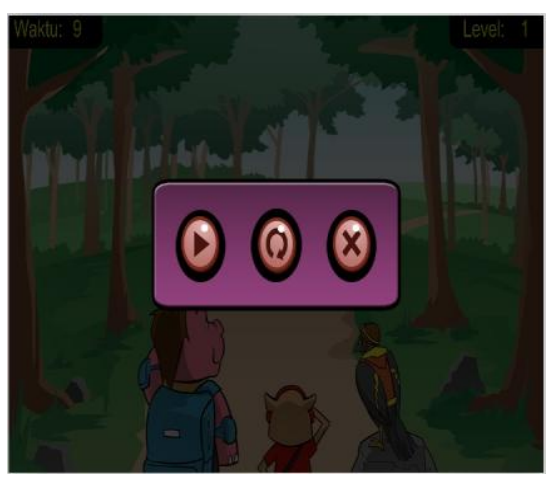

Gambar 28. Menu Popup

g. Implementasi Menu Popup 2
Menu popup 2 akan tampil ketika waktu permainan telah selesai. Pada tampilan menu popup 2 terdapat 4 menu dan skor permainan. Menu tersebut terdiri dari home, replay, next dan share ke sosial media. Menu home berfungsi untuk kembali ke menu permainan. Menu replay berfungsi untuk mengulangi permainan pada level yang sama dan menu next untuk menuju ke level selanjutnya.

\section{Kesimpulan}

Berdasarkan hasil penelitian, penerapan game ini dapat membawa efek positif dalam proses pembelajaran, namun terdapat beberapa hal yang perlu penulis sarankan bagi pengembangan sistem ini antara lain:

1. Dari variasi permainan yang ada, dapat dikembangkan lagi menjadi level-level berikutnya dengan pengembangan tingkat kesulitan dan pengembangan environment yang lebih luas.

2. Variasi soal yang ada hendaknya ditambah untuk mengurangi kemungkinan munculnya kebosanan pemain dalam memainkan game ini.

\section{Saran}

Apabila game ini akan diterapkan untuk pembelajaran yang lain, hendaknya pembelajaran dapat diterapkan ke dalam template yang dapat diubah isinya sehingga pokok bahasan dan segmen pengguna dapat diperluas.

Diperkenalkan lebih luas dan salah satunya dibuat tutorial tentang simulator Corona SDK.

\section{Daftar Pustaka}

[1]. Ahmad Zuli Amrullah.Analisis Dan Perancangan Game Petualangan "Jumper" Berbasis Android. Stmik Amikom Yogyakarta.2013

[2]. Ali Zaki. memanfaatkan beragam teknologi Digital, salemba infotek [e-book]

[3]. Hanif Al Fatta. 2007. Analisis dan perancangan system informasi, ANDI. STMIK Amikom Yogyakarta [e-book].

[4]. Coronalabs.(2013). Corona SDK The Ultimate 2D Development Platform. Diambil 29 Agustus 2013, dari http://www.coronalabs.com/products/coronasdk/.

[5]. Coronaprojectmanajer. (2013). Developers Around The World Are Using Corona ProjectManager To Create Cool Games and Apps Like These. Diambil 29 Agustus 2013, dari http://coronaprojectmanager.com/

[6]. Dwi Juli Prabowo.Analisis Dan Perancangan Game "Capsa" Berbasis Android. Stmik Amikom Yogyakarta.2013 
http://abudt27.blogspot.com/2013/05/aplikasicorona.html Diambil 27 November 2013 pukul 23.45

[7]. Irvan Dwi Efendi.Analisis Dan Perancangan Game "Ular Tangga" Pada Sistem OperasiAndroid Menggunakan Java Eclipse. Stmik Amikom Yogyakarta.2013

[8]. Luky Febrianto .Analisis Dan Perancangan Game Android Kopi Luwak. Stmik Amikom Yogyakarta.2014

[9]. Nilwan Agustinus. 1998. Pemrograman Animasi dan Game Profesional, Elex Media Komputindo, Jakarta.

[10]. Salen, Katie; Zimmerman, Eric. 2003. Rules of Play: Game Design Fundamentals, MIT Press. [e-book]
[11]. Sigit Ardhi Nugroho.Analisis Dan Perancangan Game "Apakah Kamu Lebih' Pintar Dari Anak Sd?" Berbasis Android. . Stmik Amikom Yogyakarta.2013.

[12]. Simarmata Janner.2009:Rekayasa Perangkat Lunak .penerbit ANDI. Yogyakarta

[13]. Sutabri ,Tata.2003.Analisa Sistem Informasi.penerbit ANDI. Yogyakarta

[14]. Yogiyanto.2005.Pengenalan Komputer.penerbit ANDI. Yogyakarta

[15]. Zechner Mario. 2011. Beginning Android Game, Apress [e-book]. 